\title{
Furrow Irrigation for Corn Cultivation in Hydromorphic Soils
}

\author{
Miguel Chaiben Neto ${ }^{1}$, Adroaldo Dias Robaina ${ }^{1}$, Marcia Xavier Peiter ${ }^{1}$, Rafael Ziani Goulart ${ }^{2}$, \\ Elisa de Almeida Gollo ${ }^{1}$, Jhosefe Bruning ${ }^{1}$, Bruna Dalcin Pimenta ${ }^{1}$, Silvana Antunes Rodrigues ${ }^{1}$, \\ Yesica Ramirez Florez \& Vinício José Bordignon ${ }^{2}$ \\ ${ }^{1}$ Department of Rural Engineering, Federal University of Santa Maria, Santa Maria, Rio Grande do Sul, Brazil \\ ${ }^{2}$ Federal Institute of Education Science and Technology Farroupilha, Alegrete Campus, Alegrete, Brazil \\ Correspondence: Miguel Chaiben Neto, Postgraduate Program in Agricultural Engineering, Federal University \\ of Santa Maria, Av. Roraima, $\mathrm{n}^{\circ}$ 1000, 97105-900, Santa Maria, Rio Grande do Sul, Brazil. E-mail: \\ miguelcheiben@gmail.com
}

Received: April 24, 2019

Accepted: June 3, 2019

Online Published: August 15, 2019

doi:10.5539/jas.v11n13p295

URL: https://doi.org/10.5539/jas.v11n13p295

\begin{abstract}
The use of crop rotation in hydromorphic soils has been intensified in the state of Rio Grande do Sul, Brazil. Due to the difficult management of these soils, the use of irrigation is fundamental to increase the reliability of these production ecosystems. The present study aimed to evaluate the growth and yield components of corn under different managements of furrow irrigation. The study was conducted in Alegrete/RS in the experimental area of the Farroupilha Federal Institute during the 2017/2018 season. Two factors were evaluated: five managements of furrow irrigation, with a control (not irrigated) and 0, 25, 50 and $100 \%$ of the time required to replace the irrigation depth up to field capacity, and the influence of plant position relative to the total length of the furrow, at 0,25 and 50 meters from its beginning. During the growth stage of corn, its LAI showed better performance for the three collections, at 34, 54 and 76 DAS, and plant height and shoot dry matter showed differences at 76 DAS in treatments that received irrigation. Yield components such as number of grains per ear, harvest index and grain yield were influenced by the use of irrigation, whereas water use efficiency did not differ between the use of irrigation and the control treatment. Lastly, best performances of application efficiency were found in treatments with $0 \%$ and $25 \%$ of the time required to replace the irrigation depth.
\end{abstract}

Keywords: crop rotation, irrigation efficiency, ridges

\section{Introduction}

The area cultivated with rice in Brazil in the 2017/18 season was 1.94 million hectares, with a yield of $5,802.0$ $\mathrm{kg} \mathrm{ha}^{-1}$. The Rio Grande do Sul state is the largest producer of this cereal in Brazil, with an annual cultivated area between 1.0 and 1.1 million hectares, producing 7,293.0 $\mathrm{kg} \mathrm{ha}^{-1}$ on average in the 2017/18 season (CONAB, 2018), predominantly using flood irrigation.

Areas cultivated with irrigated rice in the state are infested by weeds, and red rice is the main invasive species, directly interfering with yield and remuneration paid to producers. The main difficulty in controlling red rice is because it belongs to the same family as the cultivated rice and, in addition, seed dormancy leads to uneven germination during the rice crop cycle (Rubin et al., 2014; Sartori et al., 2014; Souza et al., 2012).

Crop rotation is an alternative to reduce weed infestation in irrigated rice areas because it helps break the cycles of diseases and control invasive species (Vernetti Jr et al., 2009; Souza et al., 2012). The corn crop is widely used in rotation systems and can be grown in different periods of the year (Buso \& Arnhold, 2016).

In Rio Grande do Sul, corn sowing in irrigated production systems is preferably carried out in October, since its highest demand for solar radiation and largest leaf area will occur from December to January. The occurrence of water deficit during the tasseling and grain filling stages is extremely harmful to the yield of the crop (Serpa et al., 2012; Vian et al., 2016).

In order to reduce stresses caused by the environment to the crop, corn can be used in rotation with irrigated rice, adopting adequate management techniques. One of them is the use of ridges for sowing because the formation of furrows between the cultivation rows helps both drainage and irrigation, favoring the utilization of corn in this context (Sartori et al., 2015; Faraco et al., 2016; Giacomeli et al., 2016). 
The use of surface irrigation in these areas is favored because all the necessary structure already exists. In addition, the use of irrigation favors better development of the crop, directly influencing its components of production and, according to Sui (2018), it is necessary to guarantee the production of the crops.

Hydromorphic soils are characterized, according to Azouzi et al. (2015), for long periods of water saturation. In addition, according to Van Breemen and Buurman (1998), the presence of a slowly permeable horizon and the periodic changes cause redox processes, which result in the typical marbled appearance of the diagnostic horizon. Although several authors have directed their studies to make alternative crops viable in hydromorphic soils, results referring to furrow irrigation are still scarce. Therefore, this study aimed to evaluate the growth and yield components of the corn crop under different managements of furrow irrigation.

\section{Methodology}

The study was conducted during the 2017/18 season, in the lowland experimental area of the Farroupilha Federal Institute (IFFar)-Campus of Alegrete, in the west border physiographic region in the state of Rio Grande do Sul, Brazil, located at altitude of 90 meters, at $29^{\circ} 42^{\prime} 57.43^{\prime \prime} \mathrm{S}$ and $55^{\circ} 31^{\prime} 54.10^{\prime \prime} \mathrm{W}$. The climate of the region, according to Köppen's classification (Moreno, 1961) is Cfa, humid subtropical without dry season and with average temperatures of $14.3{ }^{\circ} \mathrm{C}$ in the winter and $26.3{ }^{\circ} \mathrm{C}$ in the summer, and average annual precipitation of $1400 \mathrm{~mm}$. The soil of the experimental area is classified as Gleissolo Melânico típico (Entisol) (Dos Santos et al., 2018 ) and, according to its physical analysis, it has a silt loam texture, with bulk density of $1.54\left(\mathrm{~g} \mathrm{~cm}^{-3}\right)$ and total porosity of $41.60 \%$, with $36.64 \%$ of macropores and $63.36 \%$ of micropores.

The experiment was carried out in a randomized block design with a two-factor arrangement. The first factor evaluated was the influence of different irrigation depths, determined by the times of water replacement in soil at the end of each experimental unit, with a control treatment with no irrigation (N.I.); D1: $0 \%$, which consisted of only the time of water advance in the furrow; D2: $25 \%$; D3: $50 \%$ and D4: $100 \%$ of the time necessary to replace the required water depth up to field capacity at the end of each experimental unit. The second factor evaluated was the position relative to the initial part of the irrigation furrow, namely A1: beginning of the furrow (zero meter); A2: middle of the furrow ( 25 meters) and A3: end of the furrow (50 meters), and the collections were carried out as close as possible to these distances. The furrows were built with $0.1 \%$ slope and the experimental units were $3 \mathrm{~m}$ wide and $50 \mathrm{~m}$ long, totaling $150 \mathrm{~m}^{2}$.

Furrows and ridges were built concomitantly to the sowing, using a seeder-fertilizer machine with a furrowing mechanism, which performs the three operations simultaneously. The seeder has 6 furrowing shanks in the sowing lines for fertilizer placement and 3 moldboard mechanisms, responsible for creating furrows and ridges.

Corn sowing was carried out on December 7, 2017, using the early-cycle hybrid Agroceres AG 8780 VT PRO3 at sowing density of 70,000 plants per hectare. Basal fertilization was performed according to soil chemical analysis, using $140 \mathrm{~kg} \mathrm{ha}^{-1}$ of nitrogen $(\mathrm{N}), 150 \mathrm{~kg} \mathrm{ha}^{-1}$ of phosphorus (P) and $140 \mathrm{~kg} \mathrm{ha}^{-1}$ of potassium (K). The fertilizer applied had a 5:20:20 formulation and $400 \mathrm{~kg} \mathrm{ha}^{-1}$ were distributed along the sowing line. The remaining portion necessary to meet the recommendation was applied as top-dressing; nitrogen was split into two applications of $90 \mathrm{~kg} \mathrm{ha}^{-1}$, at V3 and V6 stages.

Plant analyses were conducted at the positions of beginning, middle and end of each experimental unit. Leaf area index (LAI), shoot dry matter and culm diameter were evaluated at the stages V6, V10 and VT, respectively, by collecting 5 plants at each position. Yield components were evaluated by collecting ears within a $5 \mathrm{~m}^{2}$ area at the three positions evaluated.

Water was distributed in the furrows using poly-pipes with 1 " outlets during the phase of water advance in the furrow and $3 / 4$ " outlets during the phase of replacement of the irrigation depth required. Soil volumetric moisture was monitored by $10 \mathrm{HS}$ capacitance sensors and the data were stored in a datalogger along the entire crop cycle. During the phase of water advance, the flow rate used was $0.80 \mathrm{~L} \mathrm{~s}^{-1}$, which is the maximum flow rate not to cause soil erosion. After this phase, the initial flow rate was reduced by $50 \%$ and remained constant during the entire phase of irrigation depth replacement. As a criterion, the reference adopted, according to Sartori et al. (2015), was the average limit of soil moisture in the layer of $0.0-0.2 \mathrm{~m}$ equal to $60 \%$ of the upper limit of soil water availability.

The water volume drained at the end of the experimental unit was quantified using flat-bottom gutter installed at the end of the furrow, which was calibrated and showed the following equation:

$$
\mathrm{Q}_{\mathrm{f}}=0.3488 \cdot \mathrm{h}^{1.1651}
$$

where, $\mathrm{Q}_{\mathrm{f}}=$ Outlet flow rate $\left(1 \mathrm{~min}^{-1}\right) ; \mathrm{h}=$ Water level height $(\mathrm{cm})$. 
Application efficiency was determined by subtracting the volume drained at the end of the furrow from the volume of water applied at the beginning of the experimental unit. Water use efficiency was calculated based on the total irrigation depth and the effective precipitation according to the methodology proposed by Millar (1978), which considers a surface runoff of $30 \%$ for conditions that are similar to those of the experimental area.

The obtained data were subjected to the test of assumptions of the mathematical model (normality and homogeneity of variances). Analysis of variance was carried out by F test at 0.05 probability level. Differences between means were compared by Tukey test. Both analyzes were performed in Sisvar 5.6 software.

\section{Results and Discussion}

Figure 1 demonstrates the distribution of precipitations and irrigations carried out along the period of corn crop cultivation.

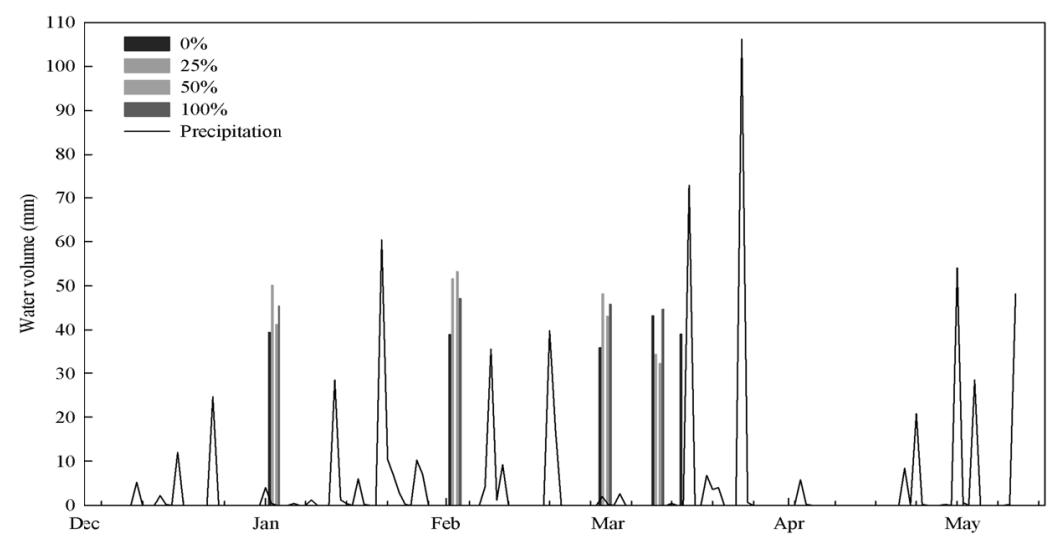

Figure 1. Distribution of precipitations and irrigations during the 2017/2018 season for the corn crop

According to Figure 1, the treatment with $0 \%$ of the time of water depth replacement at the end of the furrow, only the phase of water advance, required 5 irrigations. In the others, 4 irrigations were sufficient to meet the water requirement of corn plants. Irrigations were carried out at 26, 57, 83, 92 and 95 days after sowing (DAS).

Table 1 presents the results of collections performed at 34, 54 and 76 days after sowing (DAS). 
Table 1. Corn growth components as a function of irrigation depths

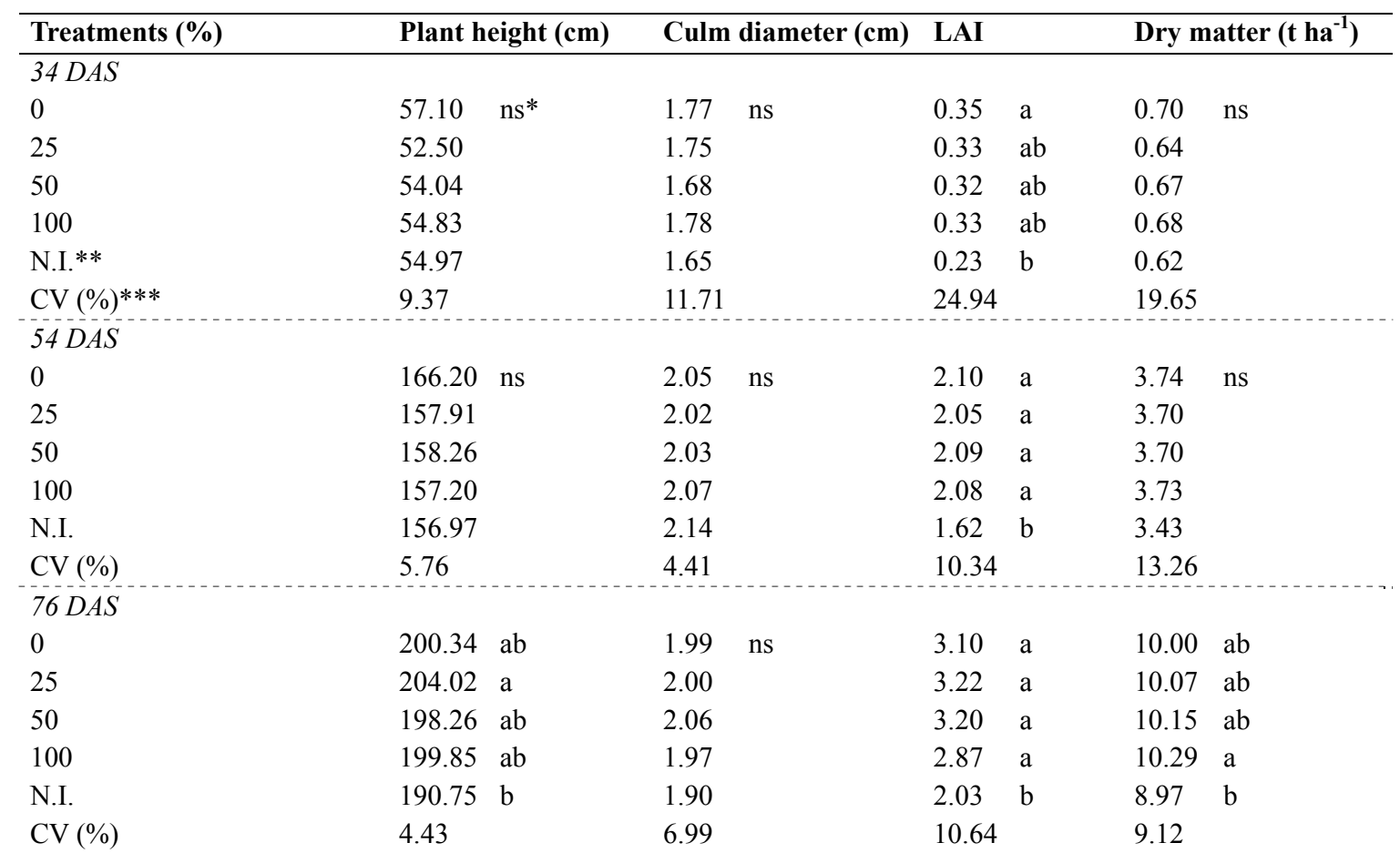

Note. Means followed by the same letter do not differ significantly in the column; *means do not differ significantly; ** not irrigated; $* * *$ coefficient of variation.

As can be seen in Table 1, culm diameter was not influenced by irrigations along the growth of the crop, whereas plant height and shoot dry matter showed better performance in irrigated treatments only in the last collection, at 76 DAS, with no difference between treatments with irrigation. Corroborating these results, Gollo (2016) conducted an experiment in Planossolo (Alfisol) to evaluate the effect of furrow irrigation on the corn crop and found no difference between treatments during the vegetative growth period for plant height and culm diameter.

Leaf area index (LAI) showed better performance in irrigated treatments in the three analyses carried out during the corn growth period. Fiorin et al. (2009), in experiment conducted in two seasons influenced by the phenomenon El Niño, obtained similar LAI for treatments in ridges with and without irrigation. In the present study, however, LAI was influenced by the irrigations because, during the growth stage, there was a period without precipitation in the initial stage of crop establishment (18 to 38 DAS).

The position along the experimental unit did not cause significant difference in the corn growth components evaluated. The precipitation regime during the vegetative period favored corn growth in the non-irrigated treatment because, immediately after the irrigations for the 4 treatments, precipitations occurred and increased the volume of water stored in soil. As a result, plant growth was not affected by water deficit, which justifies the better performance of treatments with irrigation. According to Baumhardt et al. (2013); Benjamin et al. (2015), under conditions of scarcity in the water supply, an adequate water supply in the reproductive period should be prioritized for the crop, because this is the most sensitive stage to water deficit, which may cause severe reductions in grain yield.

According to Astuce and Tic (2011), there are critical parameters to determine the yield of the pasture: the soil characteristics, the time between two irrigations and the amount of water per irrigation. The highest yields, according to Trolard et al. (2016), are obtained in hydromorphic soils or in soils with the highest water retention capacity. 
Table 2. Yield components of corn for the 2017/2018 season: ear diameter, number of grains per ear, harvest index and grain yield

\begin{tabular}{|c|c|c|c|c|}
\hline Treatments & Ear diameter (cm) & Number of grains per ear & Harvest index & Grain yield $\left(\mathrm{kg} \mathrm{ha}^{-1}\right)$ \\
\hline \multicolumn{5}{|c|}{ Irrigation depths } \\
\hline 0 & $5.130 \mathrm{~ns}^{*}$ & $456.81 \quad \mathrm{a}$ & $0.485 \mathrm{a}$ & $7.917 .80 \quad \mathrm{a}$ \\
\hline 25 & 5.055 & 460.48 a & 0.492 a & $7.570 .13 \mathrm{a}$ \\
\hline 50 & 5.058 & $459.63 \mathrm{a}$ & 0.488 a & $7.914 .28 \mathrm{a}$ \\
\hline 100 & 5.134 & $451.75 \mathrm{a}$ & 0.477 a & $7.481 .18 \mathrm{a}$ \\
\hline N.I.** & 4.980 & $400.57 \mathrm{~b}$ & $0.404 \mathrm{~b}$ & $5.166 .22 \mathrm{~b}$ \\
\hline $\mathrm{CV}(\%)^{* * *}$ & 2.84 & 7.59 & 6.33 & 18.51 \\
\hline \multicolumn{5}{|c|}{ Position in the experimental unit } \\
\hline Beginning & $5.055 \mathrm{~ns}$ & $452.83 \mathrm{~ns}$ & $0.463 \mathrm{~ns}$ & $7.214 .50 \mathrm{~ns}$ \\
\hline Middle & 5.099 & 446.71 & 0.470 & 7.546 .34 \\
\hline End & 5.061 & 438.02 & 0.476 & 6.868 .93 \\
\hline $\mathrm{CV}(\%)$ & 2.84 & 7.29 & 6.33 & 18.51 \\
\hline
\end{tabular}

Note. Means followed by the same letter do not differ significantly in the column; * means do not differ significantly; $* *$ not irrigated: $* * *$ coefficient of variation.

Based on Table 2, it can be inferred that the number of grains per ear and harvest index differed significantly between the irrigation depths applied and the non-irrigated treatment. For the positions along the experimental unit, there was no significant difference between treatments. However, the results showed a variation of $677 \mathrm{~kg}$ $\mathrm{ha}^{-1}$ ) between the positions middle and end of the experimental unit. Such reduction of yield at producer level must be considered in the planning of the plantations.

Maas et al. (2015), in a study conducted in the 2013/14 season with 4 corn hybrids and two irrigation systems (sprinkler and furrow), in the city of Cachoerinha at the Central Depression of Rio Grande do Sul, in a Gleissolo Háplico típico (Entisol), found differences in the yield components between irrigated and non-irrigated treatments. The treatment under furrow irrigation showed an average of 518 grains per ear for the four hybrids tested, whereas in the treatment without irrigation the number of grains per ear was only 182 . The results obtained in the present study for irrigated treatments were similar to those mentioned above, but the value found in the treatment without irrigation was 2.2 times higher than that found by these authors.

Faraco et al. (2016), in an experiment conducted with furrow and flood irrigation, evaluating three positions along the plot with $0.08 \%$ slope, found no significant difference in the yield components in analyses carried out along the experimental unit under furrow irrigation management. By contrast, in the treatment under flood irrigation, the end of the plot showed a significant reduction of grain yield. The results found by Maas et al. (2015) and Faraco et al. (2016) are consistent with those observed in the present study, in which the position along the plot had no influence on corn yield components and the use of irrigation techniques resulted in their increment.

Zheng et al. (2019) conducted a global survey of data published from 1970 to 2018 for the corn crop, containing 1490 field observations in 21 countries, with experimental data divided into irrigated and non-irrigated. As research results, these authors found in irrigated treatments significant increases of $14.90 \%, 8.34 \%$ and $8.43 \%$ in the number of grains per ear, ear diameter and harvest index, respectively. These results corroborate those found here, where the increments in the number of grains per ear and harvest index were $14.03 \%, 14.95 \%, 14.74 \%$, $12.77 \%$ and $20.00 \%, 21.78 \%, 20.79 \%, 18.06 \%$, respectively, for treatments with $0,25,50$ and $100 \%$ of the time to replace the required water depth. For ear diameter, the result was lower than those found by these authors and did not differ between the treatments tested.

Non-irrigated and irrigated treatments differed with respect to crop yield, which increased by $53.26 \%, 46.53 \%$, $53.19 \%$ and $44.81 \%$ in the treatments with $0,25,50$ and $100 \%$ of the time required to replace the irrigation depth For Zheng et al. (2019), complementary irrigation along corn development with a $146 \mathrm{~mm}$ water depth contributed to a $30.35 \%$ increase in grain yield. The increment of grain yield was superior in the present study, but the irrigation depth applied in all irrigated treatments was larger than that used by the above-mentioned authors. 
There was a total precipitation of $497 \mathrm{~mm}$ along the experiment, measured by the meteorological station installed close to the experimental area. Figure 2 demonstrates the monthly precipitations during the experiment and the monthly means of the years from 2007 to 2017 for the same meteorological station.

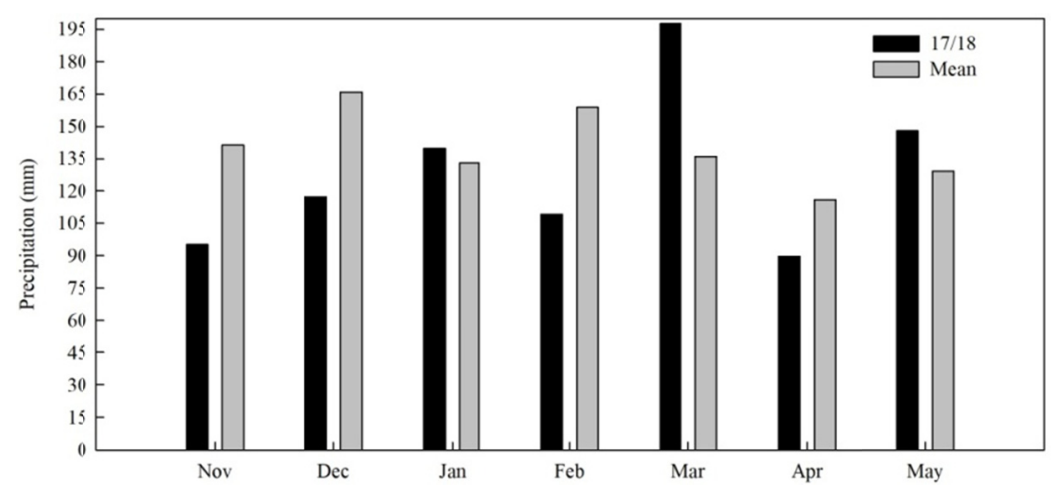

Figure 2. Monthly precipitation of the 2017/18 season and monthly mean precipitation over 10 years

According to Figure 2, the volume of precipitation that occurred during corn cultivation is sufficient for good development, but the irregular distribution of precipitations, high evaporative demand and low water storage capacity of lowland soils can cause periods of water deficit for the corn crop, requiring the use of irrigation to overcome such deficit (Gomes et al., 2006). The effective precipitation during corn cultivation was $348 \mathrm{~mm}$. This volume is $14.95 \%$ smaller than the minimum recommended for good crop development (Matzanauer et al. 2002; Bergamaschi et al. 2006).

Table 3. Total depth (TD), mean irrigation depth (MID), water use efficiency (WUE) and application efficiency (AE)

\begin{tabular}{lllll}
\hline Treatments & TD $(\mathrm{mm})$ & MID $(\mathrm{mm})$ & WUE $\left(\mathrm{kg} \mathrm{ha}^{-1} \mathrm{~m}^{-3}\right)$ & AE $(\%)$ \\
\hline 0 & $505.33 \mathrm{a}$ & 39.00 & $1.58 \mathrm{~ns}^{*}$ & $89.46 \mathrm{a}$ \\
25 & $517.40 \mathrm{a}$ & 42.00 & 1.51 & $81.66 \mathrm{a}$ \\
50 & $532.16 \mathrm{a}$ & 46.00 & 1.48 & $69.01 \mathrm{~b}$ \\
100 & $530.73 \mathrm{a}$ & 46.00 & 1.41 & $50.71 \mathrm{c}$ \\
N.I** & $347.90 \mathrm{~b}$ & & 1.50 & \\
CV $(\%)^{* * *}$ & 5.13 & & 13.52 & 6.99 \\
\hline
\end{tabular}

Note. Means followed by the same letter do not differ significantly in the column; * means do not differ significantly; $* *$ not irrigated; $* * *$ coefficient of variation.

Table 3 demonstrates that irrigation management did not influence water use efficiency, and the total depth applied in the crop did not differ between irrigated treatments. On the other hand, the application efficiency differed significantly and treatments with 50 and $100 \%$ of the time of water replacement had the lowest results.

For Marouelli et al. (2012), full furrow irrigation with $100 \%$ of the time of irrigation depth replacement has an efficiency usually close to $50 \%$, which is considered low. Paz et al. (2000) attributed an even lower efficiency, with values close to $45 \%$ for these irrigation systems, and emphasize the importance of developing new managements to improve application efficiency in these systems. Corroborating these results, the present study obtained similar values of application efficiency, $50.71 \%$ for irrigation management with $100 \%$ of water depth replacement.

The search for managements that improve furrow irrigation efficiency has been the focus of several studies. In China, the use of alternate-furrow irrigation, in which only one side of the root system is irrigated in each event, has proven to be an alternative to improve irrigation efficiency compared to full furrow irrigation (Liu et al., 2019).

Flores-Gallardo et al. (2014), searching for alternatives of irrigation management to improve the low efficiency of furrow irrigation systems in the district of Rio Forte in Sinaloa, Mexico, conducted an experiment with corn 
evaluating alternate furrows, flow rate reduction and conventional irrigation. The techniques alternative to the conventional one (full irrigation) obtained good results, reaching application efficiency above $80 \%$ for the management with flow rate reduction and $90.18 \%$ for alternate furrows, resulting in a possible water saving of up to $40 \%$.

The best application efficiencies obtained in the present study were $89.46 \%$ and $81.66 \%$, in the treatments with 0 and $25 \%$ of the time of water replacement, respectively, leading to water saving of $38.75 \%$ and $30.95 \%$. In addition to the environmental importance of saving water, these more efficient managements are alternatives to its better use. Moreover, since water consumption is high when corn is used in rotation with irrigated rice, reducing such consumption in these areas of rotation is essential to avoid shortage of water for either crop.

\section{Conclusions}

For the irrigation managements used in the present study, the evaluated positions along the experimental unit did not cause differences in corn growth and yield components for the size of the plots tested.

Yield components positively responded to the use of irrigation. For grain yield, there were increments of $44.81 \%$ and $53.26 \%$ in the treatments with $100 \%$ and $0 \%$ of the time of irrigation depth replacement, respectively, compared to the non-irrigated treatment.

Corn growth and yield components were not influenced by the irrigation managements.

Irrigation managements with $0 \%$ and $25 \%$ of the time necessary to replace the irrigation depth obtained the best application efficiencies.

\section{References}

Astuce \& Tic. (2011). Anticipation de l'Aménagement Sécurisé des Territoires Urbanisés, des Campagnes et leur Environnement par les Technologies de l'Information et de la Communication. De Mordant de Massiac J.C., Trolard F. and Bourrié G. Coord., Rapport Final du Programme FUI (2008-2011).

Azouzi, R., Charef, A., \& Hamzaoui, A. H. (2015). Assessment of effect of $\mathrm{pH}$, temperature and organic matter on zinc mobility in a hydromorphic soil. Environmental Earth Sciences, 74(4), 2967-2980. https://doi.org/ $10.1007 / \mathrm{s} 12665-015-4328-4$

Baumhardt, R. L., Schwartz, R., Howell, T., Evett, S. R., \& Colaizzi, P. (2013). Residue management effects on water use and yield of deficit irrigated corn. Agronomy Journal, 105(4), 1035-1044. https://doi.org/ 10.2134/agronj2012.0362

Benjamin, J. G., Nielsen, D. C., Vigil, M. F., Mikha, M. M., \& Calderon, F. (2015). Cumulative deficit irrigation effects on corn biomass and grain yield under two tillage systems. Agricultural Water Management, 159, 107-114. https://doi.org/10.1016/j.agwat.2015.05.025

Bergamaschi, H., Dalmago, G. A., Comiran, F., Bergonci, J. I., Müller, A. G., França, S., ... Pereira, P. G. (2006). Déficit hídrico e produtividade na cultura do milho. Pesquisa Agropecuária Brasileira, 41(2), 243-249. https://doi.org/10.1590/S0100-204X2006000200008

Buso, W. H. D., \& Arnhold, E. (2016). Evaluation of corn hybrids under contrasting water availability conditions. Revista Caatinga, 29(4), 927-934. https://doi.org/10.1590/1983-21252016v29n418rc

CONAB (Companhia Nacional de Abastecimento). (2018). Acompanhamento da Safra Brasileira: Grãos, 5-Safra 2017/18-(8)-Oitavo Levantamento, Maio 2018. Brasília: CONAB.

Dos Santos, H. G., Jacomine, P. K. T., Dos Anjos, L. H. C., De Oliveira, V. A., Lumbreras, J. F., Coelho, M. R., \& Cunha, T. (2018). Sistema Brasileiro de Classificação de Solos. Brasília, DF: Embrapa.

Faraco, J. R., Castro, N. M. R., Louzada, J. A., Silva, P. R. F., Schoenfeld, R., Maass, M. B., \& Pagliarini, N. (2016). Rendimento de grãos e eficiência do uso de água da cultura do milho em áreas de cultivo de arroz inundado com diferente manejo de irrigação e drenagem. Irriga, Edição Especial, Grandes Culturas, 274-290. https://doi.org/10.15809/irriga.2016v1n1p274-290

Fiorin, T. T., Spobr, R. B., Carlesso, R., Michelon, C. J., Dalla Santa, C., \& De David, G. (2009). Produção de silagem de milho sobre camalhões em solos de várzea. Pesquisa Aplicada e Agrotecnologia, 2, 147-153.

Flores-Gallardo, H., Sifuentes-Ibarra, E., Flores-Magdaleno, H., Ojeda-Bustamante, W., \& Ramos-García, C. R. (2014). Técnicas de conservación del água en riego por gravedad a nivel parcelario. Revista Mexicana de Ciencias Agrícolas, 5(2), 241-252. https://doi.org/10.29312/remexca.v5i2.963 
Giacomeli, R., Marchesan, E., Sartori, G. M. S., Donato, G., da Silva, P. R. F., Kaiser, D. R., \& Aramburu, B. B. (2016). Escarificação do solo e sulcadores em semeadora para cultivo de milho em Planossolos. Pesquisa Agropecuária Brasileira, 51(3), 261-270. http://doi.org/10.1590/S0100-204X2016000300008

Gollo, E. D. A. (2016). Sistemas de Implantação e Irrigação Por Superficie Para Cultivo de Milho em Áreas de Arroz Irrigado.

Gomes, A. D., da Silva, C. A. S., Parfit, J., Pauletto, E. A., \& Pinto, L. F. S. (2006). Caracterização de indicadores da qualidade do solo, com ênfase às áreas de várzea do Rio Grande do Sul. Embrapa Clima Temperado-Documentos (INFOTECA-E).

Liu, Y., Cui, E., Neal, A. L., Zhang, X., Li, Z., Xiao, Y., ... Hu, C. (2019). Reducing water use by alternate-furrow irrigation with livestock wastewater reduces antibiotic resistance gene abundance in the rhizosphere but not in the non-rhizosphere. Science of the Total Environment, 648, 12-24. https://doi.org/ 10.1016/j.scitotenv.2018.08.101

Maass, M. B., Da Silva, P. R. F., Schoenfeld, R., Rodrigues, J. F., Alves, J. A. S. C., \& Marafon, A. J. (2015) Desempenho agronômico de milho em áreas de arroz irrigado (pp. 834-838). Congresso Brasileiro de Arroz Irrigado. Anais... Sociedade Sul-Brasileira de Arroz Irrigado, Pelotas.

Marrenjo, G. J., de Pádua, E. J., Silva, C. A., Soares, P. C., \& Zinn, Y. L. (2016). Impactos do cultivo por longo tempo de arroz inundado em Gleissolos. Pesquisa Agropecuária Brasileira, 51(8), 967-977. https://doi.org/ 10.1590/S0100-204X2016000800009

Matzenauer, R., Bergamaschi, H., Berlato, M. A., Maluf, J. R. T., Barni, N. A., Bueno, A. C., \& Sampaio, M. D. R. (2002). Consumo de água e disponibilidade hídrica para milho e soja no Rio Grande do Sul (p. 105). Porto Alegre: Fepagro.

Marouelli, W. A., \& Silva, W. L. C. (2002). Tomateiro para processamento industrial: Irrigação e fertirrigação por gotejamento. Circular Técnica.

Millar, A. A. (1978). Drenagem de terras agrícolas: Bases agronômicas (p. 276). São Paulo: McGraw-Hill do Brasil, Ltda.

Moreno, J. A. (1961). Clima do Rio Grande do Sul (p. 42). Porto Alegre, Secretaria da Agricultura.

Paz, V. P. D. S., Teodoro, R. E. F., \& Mendonça, F. C. (2000). Recursos hídricos, agricultura irrigada e meio ambiente. Revista Brasileira de Engenharia Agrícola e Ambiental, 4(3). https://doi.org/10.1590/S141543662000000300025

Rubin, R. S., Langaro, A. C., Mariani, F., Agostinetto, D., \& Berto, R. M. (2014). Habilidade competitiva relativa de arroz irrigado com arroz-vermelho suscetível ou resistente ao herbicidaimazapyr + imazapic. Arquivos Instituto Biológico, 81(2), 173-179. https://doi.org/10.1590/1808-1657001242012

Sartori, G. M. S., Marchesan, E., Azevedo, C. F., Coelho, L. L., \& de Oliveira, M. L. (2014). Germinação de arroz irrigado e de biótipos de arroz-vermelho submetidas a diferentes temperaturas. Revista Ciência Agronômica, 45(2), 319-326. https://doi.org/10.1590/S1806-66902014000200013

Sartori, G. M. S., Marchesan, E., De David, R., Carlesso, R., Petry, M. T., Donato, G., ... da Silva, M. F. (2015). Rendimento de grãos de soja em função de sistemas de plantio e irrigação por superfície em Planossolos. Pesquisa Agropecuária Brasileira, 50(12), 1139-1149. https://doi.org/10.1590/S0100-204X2015001200003

Serpa, M. da S., da Silva, P. R. F., Sangoi, L., Vieira, V. M., \& Marchesi, D. R. (2012). Densidade de plantas em híbridos de milho semeados no final do inverno em ambientes irrigados e de sequeiro. Pesquisa Agropecuária Brasileira, 47(4), 541-549. https://doi.org/10.1590/S0100-204X2012000400010

Sousa, C. P., Bacarin, M. A., \& Pinto, J. J. O. (2012). Crescimento de espécies bioindicadoras do residual do herbicida (imazethapyr+ imazapic), semeadas em rotação com arroz Clearfield. Planta Daninha, 30(1), 105-111. https://doi.org/10.1590/S0100-83582012000100012

Sui, R. (2018). Irrigation scheduling using soil moisture sensors. Journal of Agricultural Science, 10(1), 1-11. https://doi.org/10.5539/jas.v10n1p1

Trolard, F., Bourrie, G., Baillieux, A., Buis, S., Chanzy, A., Clastre, P., ... Dussouilliez, P. (2016). The PRECOS framework: Measuring the impacts of the global changes on soils, water, agriculture on territories to better anticipate the future. Journal of Environmental Management, 181, 590-601. https://doi.org/10.1016/ j.jenvman.2016.07.002 
Van Breemen, N., \& Buurman, P. (1998) Soil formation (pp. 151-181). Springer, Netherlands. https://doi.org/ 10.1007/978-0-585-31788-5-7

Vernetti Junior, F. D. J., Gomes, A. D. S., \& Schuch, L. O. B. (2009). Sustentabilidade de sistemas de rotação e sucessão de culturas em solos de várzea no Sul do Brasil. Ciência Rural, 39(6). https://doi.org/10.1590/ S0103-84782009005000112

Vian, A. L., Santi, A. L., Amado, T. J. C., Cherubin, M. R., Simon, D. H., Damian, J. M., \& Bredemeier, C. (2016). Variabilidade espacial da produtividade de milho irrigado e sua correlação com variáveis explicativas de planta. Ciência Rural, 46(3), 464-471. https://doi.org/10.1590/ 0103-8478cr20150539

Zheng, H., Ying, H., Yin, Y., Wang, Y., He, G., Bian, Q., \& Yang, Q. (2019). Irrigation leads to greater maize yield at higher water productivity and lower environmental costs: A global meta-analysis. Agriculture, Ecosystems \& Environment, 273, 62-69. https://doi.org/10.1016/j.agee.2018.12.009

\section{Copyrights}

Copyright for this article is retained by the author(s), with first publication rights granted to the journal.

This is an open-access article distributed under the terms and conditions of the Creative Commons Attribution license (http://creativecommons.org/licenses/by/4.0/). 